\title{
The Students' Needs in Learning Research Methodology in Linguistics
}

\author{
Sukma Septian Nasution, Tito Dimas Atmawijaya, Abdul Aziz \\ Universitas Pamulang \\ E-mail: dosen02032@unpam.ac.id
}

\begin{abstract}
This study aims at investigating the students' needs analysis in learning Research in Linguistics at a university in Indonesia. Its main focus is on the students' academic needs including difficulties of the materials, learning methods, styles and goals, level of understanding on linguistic research issues, course planning, instructional materials and practices, and evaluation. Using descriptive analytical method, a set of questionnaires was employed in Likert-scale formula. It encompassed samples of 105 learners of English Letter's study program of the university. To validate the finding of the questionnaire, semi-structured interview to the lecturers and the students were also conducted. It results in that the leaners need; 1) the suitability of the materials composition for learners' need; 2) using group discussion method in learning activity; 3) a step-by-step process to support practical experience in collecting and analyzing data; 4) Overtly relating components of an academic journal article to the elements of developing a research project. The study ends with a recommendation for composing course materials of Research in Linguistics suited with the aforementioned findings.
\end{abstract}

Keywords: Need Analysis, Research in Linguistics, Students' Difficulties

\section{INTRODUCTION}

Research is internationally considered as a skill a student must experience (Munabil, et al. 2016) to brace them to face real life. In contrast, studies on empowering students' skill in research is lack of gauging (Earley, 2014, Wagner, Garner, \& Kawulich,, 2011). Whereas, the significance of research skill in working field is pivotal (Pesti, Gyori, \& Kopp, 2018) and accordingly universities are responsible to organize quality instructional practices in order to produce skillful graduates in research. There are some elements in organizing quality instructional practices. They are teaching methodologies (Nasution, Rochsantiningsih, \& Santosa, 2016, Tarigan \& Lasmunanda, 2020)), qualified teachers (Muijds, \& Reynolds, 2017), educational environment (Gurney, 2007, Ratmo $\&$ Sumartini, 2020), and representative materials (Richards, 2013). Providing representative materials is considered as the most essential yet challenging element (Hicks, 2016) which needs to be developed with strong basis (Nasution, Sukmawati, \& Sesriyani, 2020).

Qualified material goes a long way to stimulate more expectable learning outputs in the typical teaching-learning situation (Basturkmen, 2010). It 
can encourage and support respectable learning. It transmits with it integrated essential framework that make sure certain desired outcomes even in contexts where lecturer is not prepared, not reflective, unexperienced, untrained and unresponsive (Littlejohn, 2012). A learner can develop himself/ herself more independently with the aid of a qualified materials, in spite of bad, existent or non-existent teaching. One of the primary roles or functions of materials is that they offer prospects for learning (Cunningsworth, 1995; Hutchinson \& Torres, 1994). Researches focusing on examining and investigating the development of teaching materials based on need analysis had been mostly undertaken by previous studies (Quirk, 1985; Deutch, 2003: Ha, 2005; Moslemi, Moizadeh, \& Varnosfradani, 2011; Chovancov'a 2015; Menke, \& Paesani, 2019). The previous studies used a variety of approaches in developing qualified teaching materials by applying number of approaches such as integrated learning, multi-literacies framework, Task-Based Learning, Project Based Learning and several other ones. In applying one of the approaches, it must of course be based on the needs of teachers and learners.

In developing good textbook or qualified materials, there are several other aspects that should gain more attention: the primary skill of students, learning context, learning facilities and psychological aspect of the teacher (Nunan, 1994). Richards \& Rodgers (1986) highlighted the importance of teacher and learner roles in comprehending learning content through materials and tasks. The role of course materials is to be that of a tool or framework to be used by both lecturers and students. This tool can be undertaken efficiently more or less and it is subjected to the comprehension of its users having of the nature of the tool. Making mistake in selecting course materials has implicated into negative impact on the achievement of learning objectives (Jeremy, 2007). Accordingly, it can have undesirable consequence on learning outputs, learner's academic motivation and many other aspects. Thus, good textbook or qualified material plays a very important role in the achievement of the successful learning process.

As one of compulsory subjects to learn, Research Methodology in Linguistics has passed some changes in material to be given to the students of a university in Indonesia. Initially, the material was taken from original books from influential experts such as Practical Research by Leedy \& Ormrod (2014), Research Designs by Creswell (2010), and a book entitled Research on Education written by an Indonesian influential author, Sugiyono (2015). These books are excellent for those who seek understanding on research practicality in general, but less appropriate to be used for students who are interested in researches on linguistics. Then, the curriculum designer decided to use some books like Second Language Research Method in Applied Linguistics by Seliger, \& Shohamy (2013), and Research Methods in Applied Linguistics by Paltridge \& Phakiti (2015) that focus on research on linguistics. However, it was found that the books were less acceptable by the students mostly because of the content. An interview to ten students randomly chosen from 3 classes revealed that most of them found the books hard to understand for technical and high-level content presentations. 
This finding became a reflective feedback that it is hard to provide the potential books of research on linguistics to meet the students' needs without firstly including the students' perspectives (Hicks, 2016). Further, the reflective feedback also brought the writers to an effort to design a book of research on linguistics that meets the students' needs as Richards (2001) suggests that developing proper materials for students to learn is significant in making instructional practices a success. To design proper materials that meet the students' needs, analyzing the students' needs in learning research on linguistics is inevitable. Accordingly, this study aims at analyzing the needs of learning research on linguistics as an initial step to design a book of Research on Linguistics.

To fulfill this objective, needs analysis can be baseline for good textbook. It has been used as one of the main aspects and a fundamental part of academic and education practitioners' activities such as lecturers, educators, course designers, testers, evaluators, material developers, teachers as well as classroom teachers for many years (Prachanant, 2012). It is the procedure of planning on what and how a course will be designed and will run.

There were some research of need analysis conducted by previous researchers. Firstly, Nimasari (2018) carried out a study about need analysis in order to develop ESP learning module. The finding shows that students seem to have their own unstated demand when they have face to face study. It means that need analysis is needed when grasping their inner wants and hopes of learning. Secondly, Cui (2013) had conducted need analysis research on developing English Academic Module in order to develop his students' writing skills in China. This need analysis research could reveal several findings: students wants and needs in his writing classes. Finally, Hwang and Kim (2019) also conducted need analysis research to assess and evaluate students need on Korea national curriculum. Their findings provide useful insight into curriculum development and improvement for seeking educational effectiveness in EFL settings. Their study also provides helpful resources for conducting needs and evaluation analyses. Reflecting from previous research, this research will potray students needs and wants throughout Research on Linguistics course in English Department, Pamulang University.

\section{METHOD}

This survey research employs a set of questionnaires that seek input from the students' needs on materials in learning Research Methods in Linguistics. Its' practicality to run (Mayang, Nurkamto, \& Drajati, 2017) is a reason to choose. The answers from the selected participants were converted to percentage to reveal which choice is dominant over the other choices. The most frequently chosen answers were considered as the findings to be brought in developing modules of Research Methods in Linguistics for the students. This study is oriented to analyze the needs of English Literature study program of a private university in South Tangerang, Indonesia. The all 105 students undertaking Research Methods on Linguistics class were chosen as the participants. Validating the findings from the questionnaire was reached by crosschecking the dominant answer using open- 
ended interview approach to the lecturers and 10 students chosen randomly.

\section{FINDINGS AND DISCUSSION}

In this section, we divide the discussion into three points: firstly, need analysis in research field; second, need analysis in linguistics and thirdly, need analysis regarding learning method and the materials or textbook lay out.

\section{Need Analysis in Research Field}

\section{Selecting Research Topic}

Selecting a respectable topic in research may be challenging. It must be constricted and more focused as it must be interesting, yet broad enough to find adequate information. Majority of the students (73\%) felt extremely difficult in selecting the topic to begin their research. Table 1 shows how the student felt difficult to select the topic and make the title which suits their interest in research on linguistics.

Table 1. The Five-Point Scale of KnowledgeDifficulty Levels

\begin{tabular}{|c|l|r|r|}
\hline No. & \multicolumn{1}{|c|}{ Level of Difficulty } & Frequency & \multicolumn{1}{c|}{ Percent } \\
\hline 1. & Very Easy & 0 & $0 \%$ \\
\hline 2. & Easy & 0 & $0 \%$ \\
\hline 3. & Medium & 1 & $4 \%$ \\
\hline 4. & Difficult & 7 & $23 \%$ \\
\hline 5. & Very Difficult & 22 & $73 \%$ \\
\hline
\end{tabular}

Students we interviewed said that choosing a research topic in linguistics was very difficult. To start a research, the topic has a central role, but the focus of the discussion they want to research, as they said, is not easy to determine. They hoped in the interview we conducted that the steps for choosing a good topic in research will be included in the course material.

\section{Identifying Linguistic Research Problem}

In addition to difficulty in selecting the topic and title of the research, students also faced difficulty in identifying the problem in research. So, one of the students' research complexities is to identify a problem that must be investigated and studied. The identification of a problem study can be truly perplexing, not only because there is lack of ideas on subjects that would be examined, but because of the problem of formulating an academically significant, relevant and researchable issues which are interesting as it must be unique and does not solely be identical with others' works. When asked about research problem, most of the students (83\%) complained about their feeling of extremely difficult in identifying research issue. As it can be seen from Table 2.

Table 2. The Five-Point Scale of KnowledgeDifficulty Levels

\begin{tabular}{|c|l|r|r|}
\hline No. & \multicolumn{1}{|c|}{ Level of Difficulty } & Frequency & \multicolumn{1}{c|}{ Percent } \\
\hline 1. & Very Easy & 0 & $0 \%$ \\
\hline 2. & Easy & 0 & $0 \%$ \\
\hline 3. & Medium & 1 & $3 \%$ \\
\hline 4. & Difficult & 4 & $14 \%$ \\
\hline 5. & Very Difficult & 25 & $83 \%$ \\
\hline
\end{tabular}

In Addition, most of them (80\%) also alleged that formulating research questions was of the same difficulty they faced when they begin to research in linguistics. This must take some consideration for 
the textbook as most of the students felt very difficult in formulating the right question of research as Table 3 shows.

Table 3. The Five-Point Scale of KnowledgeDifficulty Levels

\begin{tabular}{|c|l|l|l|}
\hline No. & \multicolumn{1}{|c|}{ Level of Difficulty } & \multicolumn{1}{|c|}{ Frequency } & \multicolumn{1}{|c|}{ Percent } \\
\hline 1. & Very Easy & 0 & $0 \%$ \\
\hline 2. & Easy & 0 & $0 \%$ \\
\hline 3. & Medium & 2 & $7 \%$ \\
\hline 4. & Difficult & 4 & $13 \%$ \\
\hline 5. & Very Difficult & 24 & $80 \%$ \\
\hline
\end{tabular}

In interview, they stated that formulating research question is extremely important before beginning any research. But in fact, they felt still confused in making research question and formulate it in right way grammatically and in accord with logical research. They also hoped that the materials of the textbook in Research on Linguistics must suit this need. Based on this point, skill in formulating systematic question in research must be taught because it aims at exploring an existing ambiguity in an area of concerns and themes to a necessity for thoughtful enquiry. It is, then, relevant to make materials about step-by-step ways of formulating a good research question in systematic way. The good textbook that will be composed then must suit this need.

\section{Linguistic Data Collection}

Based on the result of filling out the questionnaire, majority of students (50\%) do not understand the definition of what data and data source are and how to search for, to identify and to collect them. It can be viewed from Table 4 .

Table 4. The Five-Point Scale of KnowledgeDifficulty Levels

\begin{tabular}{|c|l|r|r|}
\hline No. & \multicolumn{1}{|c|}{ Level of Difficulty } & Frequency & \multicolumn{1}{c|}{ Percent } \\
\hline 1. & Very Easy & 2 & $6 \%$ \\
\hline 2. & Easy & 3 & $10 \%$ \\
\hline 3. & Medium & 5 & $17 \%$ \\
\hline 4. & Difficult & 5 & $17 \%$ \\
\hline 5. & Very Difficult & 15 & $50 \%$ \\
\hline
\end{tabular}

The essence and the use of data in linguistics gains increased significance in an academic world where the task of documentation is most importantly one of sufficient data provision. Concerning collecting linguistic data and data source, as in the interview we conducted, students cannot determine whether one is really the data or not. They also are not able to differentiate between data and data sources and between data and object of research. In the interview conducted to them, they said it was so complex to find what kind of data that can be obtained from the branches of linguistics such as phonology, morphology, syntax, pragmatics etc.

\section{Analyzing Linguistic Data}

Analyzing data is an effort or way to process data into information so that the characteristics of the data can be understood and are useful for solving problems, especially problems related to research (Podeva \& Sharma, 2013). Analysis data is also some activities carried out to convert the data from research results into information that can later be used in drawing conclusions (Subroto, 2007). 
Table 5. The five-point scale of knowledge-difficulty levels

\begin{tabular}{|c|l|r|r|}
\hline No. & \multicolumn{1}{|c|}{ Level of Difficulty } & Frequency & \multicolumn{1}{c|}{ Percent } \\
\hline 1. & Very Easy & 0 & $0 \%$ \\
\hline 2. & Easy & 0 & $0 \%$ \\
\hline 3. & Medium & 7 & $23 \%$ \\
\hline 4. & Difficult & 10 & $34 \%$ \\
\hline 5. & Very Difficult & 13 & $43 \%$ \\
\hline
\end{tabular}

Based on the interview, students expressed their feeling confused in organizing and sorting data into patterns, categories, and basic units of description so that themes can be found and hypotheses can be formulated, as suggested by the data. Their lack of knowledge on what data is and what object of research is stipulated them to deal with the difficulty to do analysis on the obtained data. They complained about how to analyze data at the level of phonology, morphology, syntax, semantics, pragmatics, and semiotics. They also hoped that concrete steps will be taught gradually in analyzing data.

\section{Knowledge on Linguistic Branches}

Investigating students' needs analysis in developing Research on Linguistics textbook is highly needed. It aims to know to some extent the students' level of knowledge on linguistics and its branches. The students were asked to rate their level of understanding on linguistics and its branches. The result is as can be seen in Table 6 .
Figure 6. Students' Proficiency Level on Linguistics

\begin{tabular}{|c|l|l|l|}
\hline No. & \multicolumn{1}{|c|}{ Proficiency Level } & \multicolumn{1}{|c|}{ Frequency } & \multicolumn{1}{c|}{ Percent } \\
\hline 1. & Beginner & 13 & $43 \%$ \\
\hline 2. & Intermediate & 17 & $57 \%$ \\
\hline 3. & Advanced & 0 & $0 \%$ \\
\hline
\end{tabular}

Based on the Table 6, it can be concluded that most of students (57\%) understand materials on linguistics and its branches. The level of their understanding is intermediate. Yet, to validate this, we also conducted interview. The students' understanding on linguistics is in the level of intermediate if it is related to general understanding on what phonetics, phonology, morphology, syntax, semantics, pragmatics and discourse analyses. They understand these in general term, not in detail. However, they complained about their lack of ability to apply their knowledge on linguistics in research field. And they want linguistics materials must suit their needs in research.

\section{Learning Preferences and Textbook Layout}

In addition to identify problem on linguistics and researches, the English Letter's students were asked in questionnaire to rate their preferred learning method as seen in Table 7.

Figure 7. Students' Preferred Learning Method

\begin{tabular}{|c|l|l|l|}
\hline No. & \multicolumn{1}{|c|}{ Method of Learning } & \multicolumn{1}{|c|}{ Frequency } & \multicolumn{1}{|c|}{ Percent } \\
\hline 1. & Class Discussion & 15 & $50 \%$ \\
\hline 2. & Written and Oral Report & 7 & $23 \%$ \\
\hline 3. & Game & 5 & $17 \%$ \\
\hline 4. & Learning out the Class & 3 & $10 \%$ \\
\hline
\end{tabular}


There were 15 students (50\%) who took class discussion, 7 students (23\%) who chose the oral report, 5 of them (17\%) favored the game and other students $(10 \%)$ chose learn out of the class. As it can be viewed from the figure 7 , students favored to practice their research by using method of discuss and written and oral report. The Game is similarly required to gap boring condition in the lecture room. This information is essential for the lecturers as course designer that can be included in Research on Linguistics.

\section{CONCLUSION}

Needs analysis is part of the curriculum improvement and is essentially needed before a syllabus development for the course materials. The outcomes of this investigation might be applied as guiding principle for improving Research on Linguistics syllabus that might lead to increase the student's quality of research. This study is presented in order to afford a comprehension on the needs, functions and problems of the materials content of Research on Linguistics. The findings implies that the students' perspectives on proper materials are necessarily needed. Some inputs like preferences to classroom discussion rather than expository learning, their difficulties in understanding previous books, their low mastery on linguistics in general, are valuable to be brought in designing a book of Research Methods in Linguistics. It is expected to offer a reference point for gaining a wider array of input into content, project and application of Research on Linguistics by involving learners and lecturers in the planning process. Although the current study does not aim at representing all the needs, it can be expected that the sampling setting may give a fairly good design in later phase for promoting a qualified textbook in Research on Linguistics.

\section{Acknowledgment}

We thank LLDIKTI very much for funding this research in the scheme of Penelitian Dosen Pemula year 2019-2020 and the Institute for Research and Community Services or Lembaga Penelitian dan Pengabdian kepada Masyarakat of Universitas Pamulang for their valuable guidance in making this study a reality. None of this could have been conducted without their supports.

\section{REFERENCE}

Basturkmen, H. (2010). Developing Courses in English for Specific Purposes. New York: Palgrave Macmillan.

Chovancov'a, B. (2014). Needs analysis and ESP course design: Self-perception of language needs among pre-service student. CEJSH: The Central European Journal of Social Sciences and Humanities. 38(1). 4357.

Cing, L. J. (2013). Students' Perceptions of Academic Writing:A Needs Analysis of EAP in China. Language Education in Asia, Volume 4, Issue 1.

Cresswell, J. W. (1994). Research design qualitative and quantitative approaches. London: Sage Publications..

Cowling, J.D. (2007). Needs analysis: Planning a syllabus for a series of intensive workplace courses at a leading Japanese company. doi10.1016/j.esp.2006.10.003.

Cunningsworth, A. (1995). Choosing your Course Book. Heineman: Oxford University Press.

Diana, S., \& Mansur, M. (2018). Need analysis on English teaching materials for ICT students. ETERNAL: English, Teaching, Learning, and Research Journal. 4(2). 209-218. 
Earley, M. A. (2014). A synthesis of the literature on research methods education. Teaching in Higher Education, 19(3), 242-253.

Gurney, P. (2007). Five factors for effective teaching. New Zealand journal of teachers' work, 4(2), 89-98.

Ha, P.L. (2005). Munby's needs analysis' model and ESP. Asian EFL Journal. 6 (1). 1-10.

Hicks, A. (2016). Student perspectives: redesigning a research assignment handout through the academic literacies model. Journal of Information Literacy, 10(1). 30-43.

Hutchinson, T., \& Torres, E. (1994). The textbook as agent of change. ELT Journal, 48, 315-328.

Hwang, H. \& Kim, H. (2019). A comparative analysis of EFL students' needs and evaluation of English curriculum: A case study from Korea. English Teaching, 74(4), 3-28.

Indrasari, N. (2016). English for specific purposes: A need analysis at the second semester of physics education students of IAIN Raden Intan Lampung in the academic year of 2015/2016. English Education: Jurnal Tadris Bahasa Inggris. 9(1). 161-172.

Kandil, A. (n.d.). Needs analysis and the Arab learners. Retrieved from http://ilearn. $20 \mathrm{~m} . \mathrm{com} /$ research/ needs.htm

Li, J. (2014). Needs analysis of business English undergraduates and the implications to business English curriculum design. Advances in Language and Literary Studies, 5(4). 54-67. .https://doi. org/10.7575/aiac.alls.v.5n.4p.33

Littlejohn, A. (2012). Language teaching materials and the (very) big picture. Electronic Journal of Foreign Language Teaching. 9(1). 283-297.

Mackay, R. (1978). Identifying the Nature of the Learner's Needs. In: Mackay R, Mountford AJ, Editors. English for Specific. London: Longman.

Mayang, A., Nurkamto, J., \& Drajati, N. A. (2019). The needs analysis of senior high school students' reading competence in national examination: Students' perspective. Eternal: English, Teaching, Learning, and Research Journal. 5(1). 130-142
Menke, M. R., \& Paesani, K. (2019). Analyzing foreign language instructional materials through the lens of the multiliteracies framework. Language, Culture and Curriculum. 32(1). 34-49.

Moslemi, F, Moinzadeh, A, \& Varnosfradani, A.D. (2011). ESP Needs Analysis of Iranian MA Students: A Case Study of the University of Isfahan, 11 (4).

Muijs, D., \& Reynolds, D. (2017). Effective teaching: Evidence and practice. London: Sage.

Munabi, I. G., Buwembo, W., Joseph, R., Peter, K., Bajunirwe, F., \& Mwaka, E. S. (2016). Students' perspectives of undergraduate research methods education at three public medical schools in Uganda. The Pan African Medical Journal, 24. 1-8.

Nasution, S. S., Rochsantiningsih, D., \& Santosa, R. (2016). Model United Nations: Its Effectiveness to Teach Speaking from the Perspective of the Students' Learning Motivation. Unpublished Thesis.(Surakarta: Universitas Sebelas Maret).

Nasution, S. S., Sukmawati, N. N., \& Sesriyani, L. English for informatics engineering: Needs analysis. Jurnal Pajar (Pendidikan dan Pengajaran), 4(3). 478-488.

Nimasari, Elok Putri. (2018). An ESP Needs Analysis:Addressing the Needs of English For Informatics Engineering.Journal of Educators Society.

Nunan, D. (1994). The Learner-Centered Curriculum. Cambridge: Cambridge University Press.

Paltridge, B., \& Phakiti, A. (Eds.). (2015). Research methods in applied linguistics: A practical resource. Bloomsbury Publishing.

Paul D.. Leedy, \& Ormrod, J. E. (2014). Practical research: Planning and design. Kuala Lumpur: Pearson Education.

Pesti, C., Gordon Györi, J., \& Kopp, E. (2018). Student teachers as future researchers: how do Hungarian and Austrian initial teacher education systems address the issue of teachers as researchers?. CEPS Journal, 8(3), 35-57.

Piyanapa N. (2004). An analysis of the levels of communication English required by English program 
students. Unpublished Master's Thesis, University of Thai Chamber of Commerce, Bangkok.

Prachanant, N. (2012). Needs Analysis on English Language Use in Tourism Industry. Procedia: Social and Behavioral Sciences. 66 (2012) 117-125.

Quirk R (1985). The English language in a global context. In Quirk R, Widdowson HG, editors. English in the world: Teaching and learning the language and literature. Cambridge: Cambridge University Press. $1-6$.

Ratmo, R., \& Sumartini, T. (2020). Needs Analysis of Medical Personnel's English Communication Skills. Lexeme: Journal of Linguistics and Applied Linguistics, 2(2), 106-112.

Richards, J. C. (2013). Curriculum approaches in language teaching: Forward, central, and backward design. Relc Journal, 44(1), 5-33.

Richards, J.C. (2001). Curriculum Development in Language Teaching. London: Cambridge University Press.

Richards, J.C. and Rodgers, Theodore S. (1986). Approaches and Methods in Language Teaching. Cambridge: Cambridge University Press.
Seliger, H. W., \& Shohamy, E. (2013). Second language research methods-oxford applied linguistics. New York: Oxford University Press.

Sugiyono. (2010). Metode Penelitian Pendidikan Pendekatan Kuantitatif, Kualitatif, dan R\&D. Bandung: Alfabet.

Subroto, E. (2007). Pengantar Metode Penelitian Linguistik Struktural. Surakarta: UNS Press.

Tarigan, F. N., \& Lasnumanda, E. S. (2020). Online English Shadow Education: EFL Learners' Perspective. Lexeme: Journal of Linguistics and Applied Linguistics, 2(2), 70-78.

Tomlinson, B. (2007). Developing Materials for Language Teaching. London: Cromwel Press.

Wagner, C., Garner, M., \& Kawulich, B. (2011). The state of the art of teaching research methods in the social sciences: Towards a pedagogical culture. Studies in Higher Education, 36(1), 75-88.

Yocheved, D. (2003). Needs analysis for academic legal English courses in Israel: a model of setting priorities. Journal of English for Academic Purposes 2, 13(4). 125-146. 